\title{
Loyalty of Green Tourist : Mediating Role of Satisfaction
}

\author{
Nining Yuniati ${ }^{1}$, Sony Heru Priyanto ${ }^{2}$, Lieli Suharti ${ }^{3}$, \\ and Linda Kusuma ${ }^{4}$ \\ ${ }^{1}$ Sekolah Tinggi Pariwisata Ambarrukmo (STIPRAM) \\ ${ }^{2,3,4}$ Universitas Kristen Satya Wacana (UKSW)
}

Corresponding Author: niningyuniati@gmail.com

\begin{abstract}
ARTICLE INFO
Received

12 February 2020

Accepted

12 March 2020

Available online

31 March 2020

\section{ABSTRACT}

The paper aims to test a research model of the mediating role of satisfaction in creating loyalty of green tourists. The importance of loyalty refers to a number of unique characteristics of green tourists such as being associated with the middle class, high spenders, staying longer than common tourists, high involvement, and tolerance. By using SEM a mediation test was carried out related to the position of customer satisfaction (GCS) in mediating its decision to buy in an environmentally friendly hotel (GP) and its loyalty (GCL). In short, to get loyal customers, services must be created in order to encourage customer satisfaction.
\end{abstract}

Keywords: green hotel, green tourist, loyalty, purchasing, satisfaction

\section{INTRODUCTION}

Green tourists are tourists who have a high awareness of being environmentally friendly. In a study of 'new tourism' (Cecilia, Elizabeta, \& Magdalena, 2011) green tourists usually a part of new tourists who embrace 'environmentalism' who have a high awareness of the impact of their behavior on the environment. The characteristic of green tourists included prefer to choose products that are environmentally friendly,

http://ojs.unud.ac.id/index.php/eot sensitive and respectful of local culture, caring, enthusiastic in seeking new experiences, a participators rather than spectators (Lee, Tzang, Han, \& Kim, 2010). This group is also characterized by middle class social status, high spending ability, longer length of stay, and higher education (Balderjahn, 1988; Larson \& Khan, 2011). Their lifestyle leads to environmentally friendly consumption behavior (Gao \& Mattila, 2015) also well known as green consumer (Larson \& Khan, 2011). In theory of green marketing e-ISSN: 2407-392X. p-ISSN: 2541-0857 
knows as a consumer who bought ecolabels product due to their awareness about the environment (Wolok, 2019).

Green tourists usually have a mature consideration in deciding to buy a product, because of their awareness of all risks due to these actions (Joshi \& Rahman, 2015). Similarly, in choosing accommodation to stay. The decision to choose a hotel has probably been very well considered. There are at least three indicators of green purchasing decisions made by green tourists. Firstly intention to pay as conventional hotel prices, this indicator is a bargain from consumers towards environmentally friendly hotels to get services and satisfaction as good as conventional hotels (Gao \& Mattila, 2015). According to consumers' perceptions, conventional hotels are generally considered 'better' compared to green hotels in terms of comfort, price, facilities, and services (Berezan, Millar, \& Raab, 2014; Chang \& Fong, 2010; Gao \& Mattila, 2015; Kubickova, Nusari, Parsa, \& $\mathrm{Hu}, 2014$; Larson \& Khan, 2011; Young, Hwang, Donald, \& Oates, 2010). Second, the perceived of effectiveness of green behavior, according to this is a form of high consumer awareness of the environment. Consumers have perception that their actions are a part of solution to environmental problems. Third, selfaffirmation which expressly rejects the http://ojs.unud.ac.id/index.php/eot perception that environmentally friendly products are inferior, premium prices, and recycled (Chan \& Chan, 2013; Johri \& Sahasakmontri, 2016; Kusliwal \& Agarwal, 2015; Yu, Li, \& Jai, 2017). Selfaffirmation is a kind of consumer's integrity that responsibility to the environment is more important than product characteristics itself. It is possible that a number of other factors may have an influence such as social factors, psychological factors, and situational factors (Dewi, Adhianata, \& Suwignyo, 2018).

Green tourists also have a number of preferences related to the expected service especially when choosing an accommodation. A study conducted by Bastic dan Gojcic (2012) and Berezan et al. (2014) revealed that there are at least three service indicators that can satisfy green tourists, firstly green attributes which include the interior and exterior of hotel attributes; desirable facilities and hotel atmosphere, efficient use of electricity, water and a number of green actions. Second, eco staff behavior means the capacity and capabilities of hotel employees related to green behavior. In relation of the role of staff to the consumer satisfaction is also ever being empirically examined by Sundaraju, Kee, Lopez, Balakrishnan, and Sagadevan (2019) and Wisker and Kwiatek (2018). Third, the 
availability of healthy food in each food menu. All of these are part of customer satisfaction services which considered able to improve customer loyalty (Anita, 2019).

However, the number of studies related to green tourist behavior mostly examines the factors that influence decisions. Research related to efforts to make green tourists into loyal tourists has rarely found. It is a mistake if the green tourist then not treated to be a loyal consumer even if it counts a small amount. The characteristics of green tourists are the main reason why then came a thought how to make these green tourists become loyal consumers. This study has an attempt to test a model how to create loyalty for green tourist, especially for those who stay at green hotels by looking at opportunities for the role of dimensions in the services provided to ensure tourist satisfaction.

\section{HYPOTHESES DEVELOPMENT AND RESEARCH METHOD}

A number of research revealed that loyalty close relationship with satisfaction (Ganiyu, 2017; Kheng, Mahamad, Ramayah, \& Mosahab, 2010; Mohsan, Nawaz, Khan, Shaukat, \& Aslam, 2011; R.A.Ganiyu, I. Ikechuwku, \& A.O. Elizabeth, 2012; Saleem \& Raja, 2014). According to Asgharian, Saleh, Saleki,
Hojabri, and Nikkhesiat (2012) there is direct relationship between product quality and consumer loyalty. Same opinion also stated by Srivastava (2015) that customer satisfaction will influence to loyalty by some moderating factors. Green customer loyalty is a loyal attitude towards a company brand that cares about the environment, it makes consumers have an emotional bond with the product and wants to always use the same product in the future (Chang \& Fong, 2010). Consumers who feel satisfied tend to be loyal (Orie Berezan, Carola Raab, Michelle Yoo, \& Love, 2013).

Regarding to those statements, there are two hypotheses can be proposed. Firstly, a green tourist who has decision to stay at green hotel (GP) is a loyal customer. Secondly, consumer who has satisfaction on a number of service dimensions (GCS) will encourage loyalty (GCS). The two hypotheses can be formulated as follows:

H1 : Green purchasing of green tourist effect to green customer loyalty

H2 : Green Customer Satisfaction is mediating variable between green purchasing and green customer loyalty 


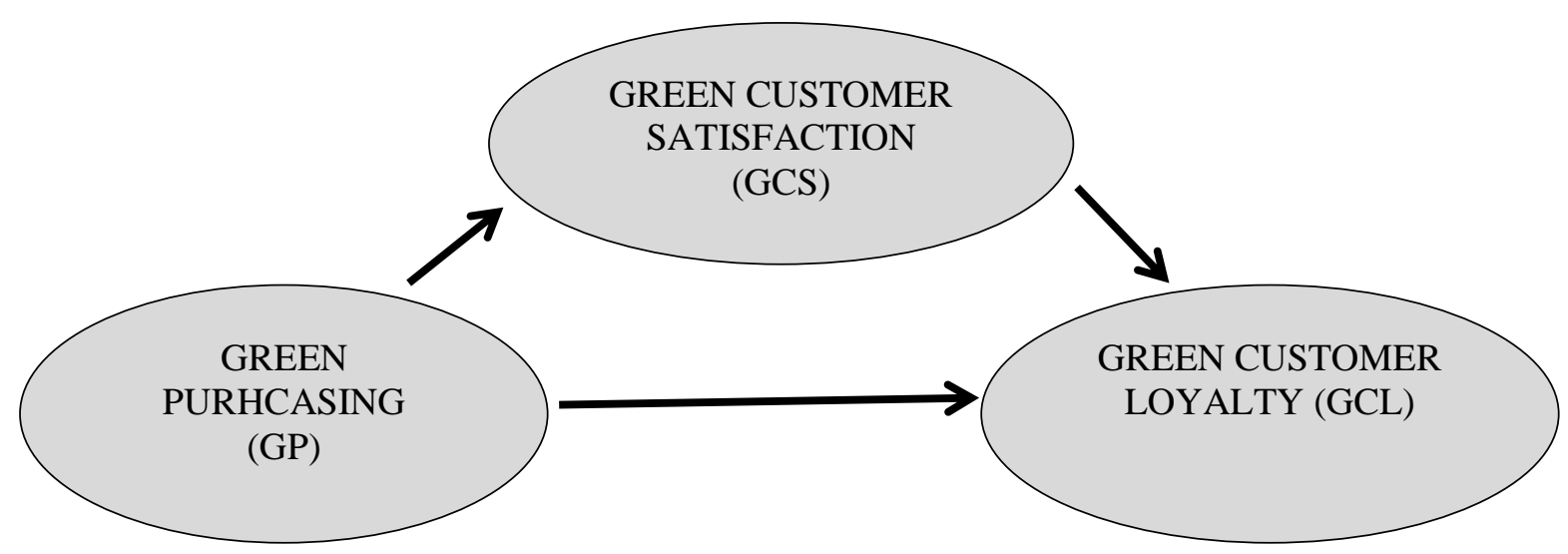

Figure 1. Theoretical Concept

This research using 296 respondents as samples. This amount is the questionnaire returned and filled out. According to (Hair, Black, babin, \& Anderson, 2014) and Tabachnick and Fidell (2013) for the number of samples in the range of 100 - 350 samples, the estimation technique approach used is maximum likelihood estimation. The sample are tourists who stay in a green hotel, they were later described in this study as green tourists. For a more indepth analysis, this study selects tourists who have chosen green hotels which are officially certified by the government. Research location is Yogyakarta that has been known as one of the most popular tourist destinations in Indonesia.

Before the questionnaire was distributed the validity of 30 respondents had been tested and no significant problems were found, so the instrument was considered able to explain the problem then the survey was continued. The instrument used was a questionnaire with questions that could be chosen on a scale of 1-5 where 1 was Strongly Disagree and 5 was Strongly Agree. The analysis technique used is Structured Equation Modeling (SEM), one of the multivariate analyzes that can analyze relationships complex variable.

The Analysis was done by AMOS version 24. Operational variables consist of Green Purchasing (GP) with 3 Indicators, the dimension of Green Customer Satisfaction (GCS) consists of 9 indicators, and the intention of loyalty or Green Customer Loyalty (GCL) consist of 5 indicators as written in Table 1. 
Table 1. Operational Variables

Variable Green Purchasing (GP)

1. Value perception; it is acceptable to pay conventional hotel prices for green hotel

2. Perceived of effectiveness i.e when buy this product means try to consider how the use of them will affect the environment ()

3. Self-affirmation i.e prefer to choose the product which less pollution

Variable Green Customer Satisfaction (GCS)

1. Feeling satisfied because hotel using ecofriendly attribute into both exterior and interior

2. Feeling satisfied because the atmosphere of a hotel is preferable (lighting, air circulation)

3. Feeling satisfied because hotel practiced efficiency in using energy in water and electricity

4. Feeling satisfied because hotel encourages guests to participate in green action (re-use towels, bed linen, refillable shampoo)

5. Feeling satisfied because employees encourage the guests about green attitude while staying in the hotel

6. Employees are responsive to the guest

7. Feeling satisfied because employees have good knowledge about green behavior

8. Feeling satisfied because hotel providing healthy food

9. Feeling satisfied because hotel provide Bio menu in all the menus offered by hotel

Variable Green Customer Loyalty (GCL))

1. It is acceptable to pay more to stay at a hotel that engages green practices

2. Willingness to re-visit, plan to stay at a green hotel again when travelling

3. Willingness to recommend by encourage friends and relatives to stay at green hotel

4. Plan to give testimonial over the social media regarding to the experience

5. Always try to seek a lot of information about green hotel while travelling

http://ojs.unud.ac.id/index.php/eot

\section{RESULTS AND DISCUSSION}

Knowing consumer loyalty is very important regarding the complicated consumer decision to buy green product (Joshi \& Rahman, 2015; Yu et al., 2017). Research on consumer loyalty of green hotel particularly has never been found, but the concept of green customer loyalty can be shown from a number of attitudes such as willingness to pay more (Dimara, Manganari, \& Skuras, 2015; Manaktola \& Jauhari, 2007) willingness to re-visit (Kubickova et al., 2014), and willingness to recommend to other consumers (Kubickova et al., 2014; Lee et al., 2010) which also tested in this paper.

The concept of loyalty from green tourist can be related to the green customer loyalty research that was first empirically examined by Chang and Fong (2010) in his research on green product and the consumer in Taiwan. It is not specifically mention what kind of product that examined. Other research conduct by Chen (2013) which examines about consumer loyalty to green electronic products. Both of studies discussed the object of manufactured products. The concept that can be captured from those studies is that there is a loyal intention of consumers to buy back and continue to use the product even if the price tag is more expensive than the common product.

e-ISSN: 2407-392X. p-ISSN: 2541-0857 
This research has the aim of testing the role of customer satisfaction in improving customer loyalty of green hotels. Based on testing results the overall validity and reliability test results are valid and reliable. According to Taherdoost (2016) the data said to be valid if value standardized regression weight $>0,5$ and the result of the calculation of all latent variables can meet the criteria construct reliability and variance extracted with all value of indicator $>0,5$ so it was concluded that the indicators observed could reflect the analyzed factors and together could reflect an unidimensionality (see Table 2).

Table 2. The Result of Validity and Reliability Test $(N=296)$

\begin{tabular}{lclc}
\hline \multicolumn{2}{l}{ Variables; Indicators } & & Estimate \\
\hline GCS & $<---$ & GP &, 636 \\
GCL & $<---$ & GCS &, 702 \\
GCL & $<--$ & GP &, 078 \\
GP1 & $<---$ & GP &, 802 \\
GP2 & $<---$ & GP &, 737 \\
GP3 & $<---$ & GP &, 797 \\
GCS1 & $<---$ & GCS &, 850 \\
GCS2 & $<---$ & GCS &, 810 \\
GCS3 & $<---$ & GCS &, 779 \\
GCS4 & $<---$ & GCS &, 837 \\
GCS5 & $<---$ & GCS &, 847 \\
GCS6 & $<---$ & GCS &, 837 \\
GCS7 & $<---$ & GCS &, 867 \\
GCS8 & $<---$ & GCS &, 840 \\
GCS9 & $<---$ & GCS &, 838 \\
GCL1 & $<---$ & GCL &, 811 \\
GCL2 & $<---$ & GCL &, 831 \\
GCL3 & $<---$ & GCL &, 807 \\
GCL4 & $<---$ & GCL &, 843 \\
GCL5 & $<---$ & GCL &, 848 \\
\hline
\end{tabular}

The next step is to know the normality of the data estimated by Maximum Likelihood. The assumption of normal data requires that the observed variable must meet the multivariate normality assumption and can be done by observing a multivariate $\mathrm{CR}$ value of \pm 2.58 at a significance of $1 \%$. Normality test result (see table 3) show that the CR value for multivariate is -0.08 or in the range -2.58 to 2.58 at a significance level of $1 \%$, so it can be concluded that the data are normally distributed (see Table 3).

Table 3. Assessment of Normality $(N=296)$

\begin{tabular}{ccccccl}
\hline $\begin{array}{c}\text { Vari- } \\
\text { able }\end{array}$ & Min & Max & Skew & C.R. & $\begin{array}{c}\text { Kurto } \\
\text { sis }\end{array}$ & C.R. \\
\hline GCL5 & 1,000 & 5,000 &,- 344 & $-2,792$ &,- 070 &,- 283 \\
GCL4 & 1,000 & 5,000 &,- 380 & $-3,085$ &,- 019 &,- 077 \\
GCL3 & 1,000 & 5,000 &,- 369 & $-2,996$ &,- 130 &,- 528 \\
GCL2 & 1,000 & 5,000 &,- 335 & $-2,724$ &,- 092 &,- 374 \\
GCL1 & 1,000 & 5,000 &,- 551 & $-4,477$ &, 221 &, 896 \\
GCS9 & 1,000 & 5,000 &,- 408 & $-3,314$ &,- 202 &,- 823 \\
GCS8 & 1,000 & 5,000 &,- 322 & $-2,615$ &,- 325 & $-1,321$ \\
GCS7 & 1,000 & 5,000 &,- 551 & $-4,477$ &, 053 &, 214 \\
GCS6 & 1,000 & 5,000 &,- 456 & $-3,707$ &, 138 &, 560 \\
GCS5 & 2,000 & 5,000 &,- 273 & $-2,215$ &,- 629 & $-2,554$ \\
GCS4 & 1,000 & 5,000 &,- 445 & $-3,612$ &, 156 &, 632 \\
GCS3 & 1,000 & 5,000 &,- 421 & $-3,424$ &,- 044 &,- 177 \\
GCS2 & 1,000 & 5,000 &,- 454 & $-3,689$ &, 222 &, 901 \\
GCS1 & 1,000 & 5,000 &,- 310 & $-2,515$ &,- 418 & $-1,700$ \\
GP3 & 2,000 & 5,000 &,- 190 & $-1,546$ &,- 664 & $-2,698$ \\
GP2 & 1,000 & 5,000 &,- 396 & $-3,213$ &, 046 &, 189 \\
GP1 & 1,000 & 5,000 &,- 279 & $-2,263$ &,- 103 &,- 420 \\
Multiva & & & & &,- 020 &,- 008 \\
riate & & & & & & \\
\hline Note. C.R = Critical Ratio. & & & \\
& & & & &
\end{tabular}


Table 4. Goodness of Fit Test Results for The Model $(N=296)$

\begin{tabular}{lccc}
\hline $\begin{array}{c}\text { Goodness of } \\
\text { fit index }\end{array}$ & $\begin{array}{c}\text { Cut off } \\
\text { Value }\end{array}$ & Result & $\begin{array}{c}\text { Evaluation } \\
\text { Model }\end{array}$ \\
\hline Chi Square & Small $(<$ & 3038,4 & Fit \\
(df = 67) & $605,666)$ & 74 & Fit \\
Probability & $\geq 0,05$ & 0,000 & Fit \\
CMIN/DF & $\leq 2,00$ & 2.082 & Fit \\
GFI & $\geq 0,90$ & 0,934 & Fit \\
AGFI & $\geq 0,90$ & 0,913 & Fit \\
TLI & $\geq 0,95$ & 0,972 & Fit \\
CFI & $\geq 0,95$ & 0.976 & Marginal \\
RMSEA & $\leq 0,08$ & 0,052 & \\
\hline \multicolumn{1}{c}{ Sig. 5\% } & & &
\end{tabular}

The results of the Inter-Variable Influence Test (see table 5), all variables and indicators show a significant influence except in GP to GCL where the purchase decision has no direct effect on loyalty ( $\mathrm{P}$ value $=0.171$ above the normal value 0.05). It is answered $\mathrm{H} 1$ that the green tourist has decided to stay at a green hotel is a loyal consumer, this opinion cannot be proven so $\mathrm{H} 1$ is rejected.
Furthermore, consumer decision (GP) has an effect on the dimensions of consumer satisfaction (GCS), which means that the services offered by the hotel are part of the attractiveness factor why choosing the hotel. The relationship between GCS and loyalty (GCL) also shows a significant $\mathrm{p}$ value, this means that the dimensions of customer satisfaction ultimately affect loyalty. Services that are in line with expectations that then make consumers satisfied are the triggers of consumer loyalty.

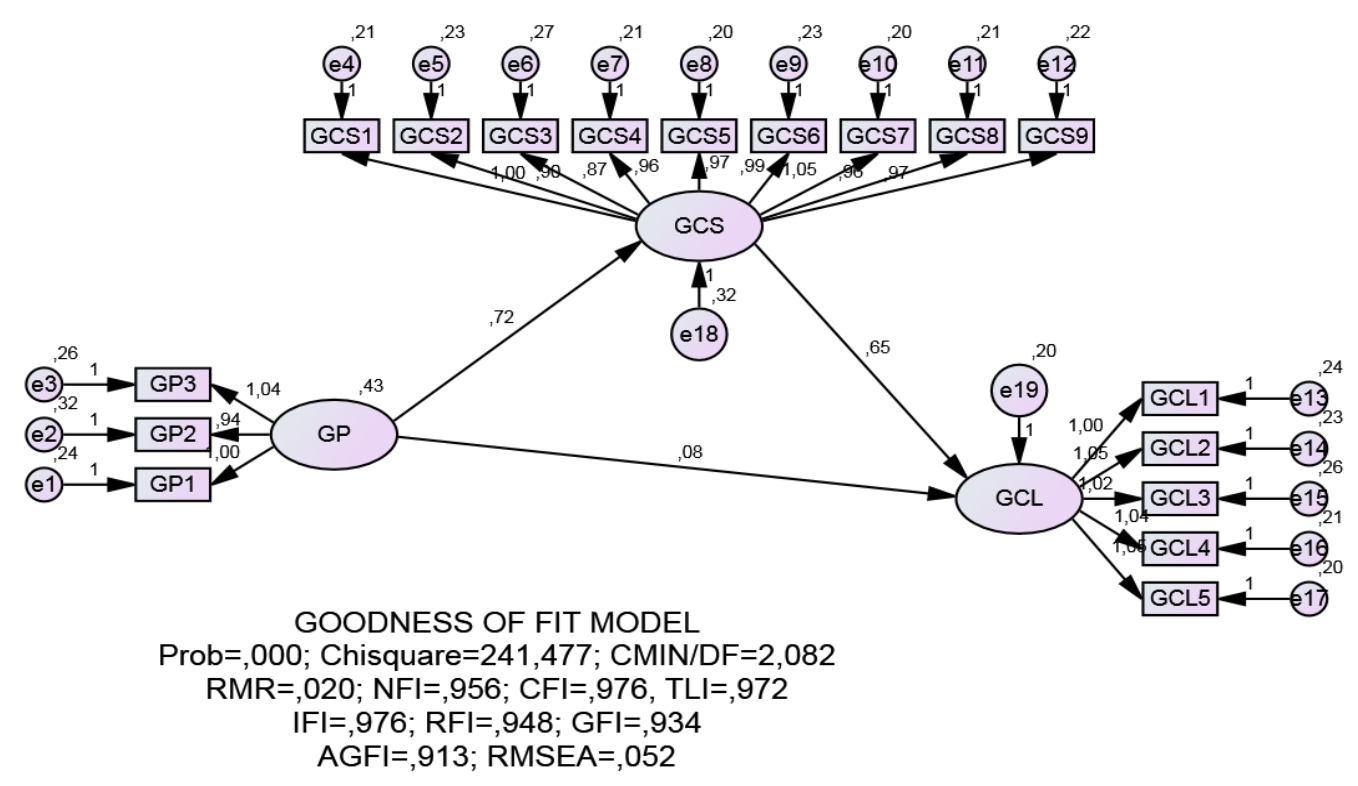

Figure 2. Result of Model Examination of SEM 
Table 5. The Result of Inter-variable Testing

\begin{tabular}{|c|c|c|c|c|c|c|c|}
\hline \multicolumn{3}{|c|}{ Hypotheses } & \multirow{2}{*}{$\begin{array}{r}\text { Estimate } \\
, 716\end{array}$} & \multirow{2}{*}{$\begin{array}{l}\text { S.E. } \\
064\end{array}$} & \multirow{2}{*}{$\frac{\text { C.R. }}{11,272}$} & \multirow{2}{*}{$\frac{\mathrm{P}}{* * *}$} & \multirow{2}{*}{$\frac{\text { Label }}{\text { par_15 }}$} \\
\hline GCS & $<--$ & GP & & & & & \\
\hline GCL & $<---$ & GCS &, 653 & ,058 & 11,265 & $* * *$ & par_16 \\
\hline GCL & $<---$ & GP & ,082 & ,060 & 1,368 & , 171 & par_17 \\
\hline GP1 & $<---$ & GP & 1,000 & & & & \\
\hline GP2 & $<---$ & GP & ,944 & ,067 & 13,991 & $* * *$ & par_1 \\
\hline GP3 & $<---$ & GP & 1,038 & 069 & 15,087 & $* * *$ & par_2 \\
\hline GCS1 & $<---$ & GCS & 1,000 & & & & \\
\hline GCS2 & $<---$ & GCS &, 898 & ,045 & 20,173 & $* * *$ & par_3 \\
\hline GCS3 & $<---$ & GCS &, 872 & ,046 & 18,921 & $* * *$ & par_4 \\
\hline GCS4 & $<---$ & GCS & 963 & ,045 & 21,503 & $* * *$ & par_5 \\
\hline GCS5 & $<--$ & GCS & 972 &, 044 & 21,928 & $* * *$ & par_6 \\
\hline GCS6 & $<---$ & GCS & ,991 & 046 & 21,408 & $* * *$ & par_7 \\
\hline GCS7 & $<---$ & GCS & 1,048 & ,046 & 22,877 & $* * *$ & par_8 \\
\hline GCS8 & $<---$ & GCS & ,965 & ,045 & 21,561 & $* * *$ & par_9 \\
\hline GCS9 & $<---$ & GCS & ,969 & 045 & 21,569 & $* * *$ & par_10 \\
\hline GCL1 & $<---$ & GCL & 1,000 & & & & \\
\hline GCL2 & $<---$ & GCL & 1,053 & ,056 & 18,828 & $* * *$ & par_11 \\
\hline GCL3 & $<--$ & GCL & 1,017 & ,055 & 18,329 & $* * *$ & par_12 \\
\hline GCL4 & $<---$ & GCL & 1,039 & 053 & 19,543 & $* * *$ & par_13 \\
\hline GCL5 & $<--$ & GCL & 1,048 &, 054 & 19,555 & $* * *$ & par_14 \\
\hline
\end{tabular}

Note. Sig. $5 \%$; S.E = Standard Error; C.R = Critical Ratio; $\mathrm{P}=$ Probability $* * *$ means $\mathrm{P}<0.001$

To answer $\mathrm{H} 2$ that Green Customer Satisfaction is mediating between Green Purchasing of Green Tourist and Green Customer Loyalty can be done by testing the direct and indirect effects of mediating variables on loyalty (GCL) (see Table 6). The test results show that the direct influence of Green Purchasing (GP) on the dimensions of consumer satisfaction (GCS) is $63.6 \%$, while the direct effect of the dimensions of consumer satisfaction (GCS) on loyalty (GCL) is $70.2 \%$.
GP has an indirect effect to GCL with $44.7 \%$. The direct influence of GCS on GCL $(70.2 \%)$ shows that the dimensions of GCS customer satisfaction as mentioned by Bastic dan Gojcic (2012), and Berezan et al. (2014) has important role to gaining green tourist loyalty. Based on this test result $\mathrm{H} 2$ is accepted.

Table 6. Standardized Direct Effects and Indirect Effects

\begin{tabular}{cccccccc}
\hline & \multicolumn{3}{c}{ Standardized Direct Effects } & \multicolumn{3}{c}{ Standardized Indirect Effects } \\
\hline & GP & GCS & GCL & & GP & GCS & GCL \\
GCS &, 636 &, 000 &, 000 & GCS &, 000 &, 000 &, 000 \\
GCL &, 078 &, 702 &, 000 & GCL &, 447 &, 000 &, 000 \\
\hline
\end{tabular}


Based on a series of test, there is a finding that green tourists actually unique, flexible, and more easily to be managed. This consumer group orientation is not solely on convenience but also on its values and contribution to the environment. Usually have high involvement and higher tolerance (Lee et al., 2010) so that actually green hotels are easier to serve this group as long as the service is associated with contributions to environmental preservation.

\section{CONCLUSIONS}

Based on the results of the study as explained and tested above, this research answered the reason for the importance to achieve green tourist loyalty with all its unique characteristics. Achieving green tourist loyalty requires a number of services with strong character and high environmental awareness. Through service dimensions such as green attributes, attitude from hotel staff, and healthy food are the factors that support tourist satisfaction. The satisfaction has an important role in mediating customer loyalty. Satisfied customers will tend to be loyal.

Accordingly, H1 was rejected, green tourist who already choose a green hotel not always a loyal customer. To create a loyal customer hotel must be able http://ojs.unud.ac.id/index.php/eot to achieve customer satisfaction. Satisfaction succeed becomes a mediation between purchasing decisions and loyalty. Therefore, H2 is accepted. Green hotels absolutely have to master and provide environmentally friendly services to be able to get loyal guests.

\section{REFERENCES}

Anita, T. L. (2019). The Effect of Brand Personality and Customer Satisfaction to Customer Loyalty at The Mall: A Study Case. International Journal of Tourism and Hospitality in Asia Pacific (IJTHAP), 2(1). doi:https://doi.org/10.32535/ijthap.v $\underline{2 \mathrm{i} 1.352}$

Asgharian, R., Saleh, M., Saleki, Z. S., Hojabri, R., \& Nikkhesiat, M. (2012). Green Product Quality, Green Customer Satisfaction, and Green Customer Loyalty IRACSTInternational Journal of Research in Management \& Technology (IJRMT), 5(2).

Balderjahn, I. (1988). Personality variables and environmental attitudes as predictors of ecologically responsible consumption patterns. Journal of Business Research, 17, 51-56.

Berezan, O., Millar, M., \& Raab, C. (2014). Sustainable Hotel Practices and Guest Satisfaction Levels. International Journal of Hospitality \& Tourism Administration, 15, 1-18. doi:http://dx.doi.org/10.1080/152564 $\underline{80.2014 .872884}$

e-ISSN: 2407-392X. p-ISSN: 2541-0857 
Cecilia, G., Elizabeta, M., \& Magdalena, B. (2011). Tourism's Changing Face : New Age Tourism versus Old Tourism. Annals - the University of Oradea, Economic Science Series, 245-249.

Chan, X., \& Chan, K. (2013). Perception of Green Hotels Among Tourist in Hong Kong : An Exploratory Research,. Service Marketing Quarterly, 34, 339-352. doi:https://doi.org/10.1080/1533296 $\underline{9.2013 .827069}$

Chang, N.-J., \& Fong, C. M. (2010). Green Quality, Green Corporate Image, Green Customer Satisfaction, and Green Customer Loyalt. African Journal of Business Management, 4(13), 2836-2844.

Chen, Y.-S. (2013). Towards Green Loyalty: Driving from Green Perceived Value, Green Satisfaction, and Green Trust. Sustainable Development, 21(5), 294-308. doi: $10.1002 / \mathrm{sd} .500$

Dewi, I. C., Adhianata, H., \& Suwignyo, A. (2018). Factors That Encourage Surabaya's Citizen In Reservation Through Offline Travel Agent (Travel Bureau) (Case Study On Pt Aneka Tours And Travel Services Surabaya). International Journal of Tourism and Hospitality in Asia Pacific (IJTHAP), 1(1). doi:https://doi.org/10.32535/ijthap.v $\underline{1 \mathrm{i} 1.105}$

Dimara, E., Manganari, E., \& Skuras, D. (2015). Willingness to pay premium for Green Hotels, Fact or fad ?,. Paper presented at the Proceedings International Marketing Trends Conference 2015, Greek State.
Ganiyu, R. A. (2017). Customer Satisfaction and Loyalty: A study of Interrelationships and Effects in Nigerian Domestic Airline Industry. Oradea Journal of Business and Economics, 2(1).

Gao, Y. L., \& Mattila, A. S. (2015). The Impact of Option Popularity, Social Inclusion/Exclusion, and Self Affirmation on Consumers Propensity to Choose Green Hotels. Business Ethic (2016) 136-575-585. doi:https://doi.org/10.1007/s10051014-2536-6

Johri, L. M., \& Sahasakmontri, K. (2016). Green marketing of cosmetics and toiletries in Thailand. Journal of Consumer Marketing, 15(3), 265281.

doi:http://dx.doi.org/10.1108/073637 $\underline{69810219134}$

Joshi, Y., \& Rahman, Z. (2015). Factors Affecting Green Purchase Behaviour and Future Research Directions International Strategic Management Review, 3, 128-143. doi:http://dx.doi.org/10.1016/j.ism.2 $\underline{015.04 .001}$

Kheng, L. L., Mahamad, O., Ramayah, \& Mosahab, R. (2010). The Impact of Service Quality on Customer Loyalty: A Study of Banks in Penang, Malaysia International Journal of Marketing Studies, 2(2).

Kubickova, M., Nusari, K., Parsa, H., \& Hu, H. H. S. (2014). Does Green Hotel Image Influence Guests' Behavior: The Case of Generation Y. Journal of Services Research, 14(2), 9-32. 
Kusliwal, N., \& Agarwal, S. (2015). An Exploratory Study on Women's Perception and Choice of Preference towards the Green Attributes of Hotel Industry. International Journal of Engineering Technologu, Management and Applied Science, 3(Special Issues).

Larson, S., \& Khan, M. A. (2011). A Study Factor That Influence Green Purchase. (Master), Umeå University Umeå University, SE-901 87 Umeå, Sweden.

Lee, J. S., Tzang, L., Han, H., \& Kim, Y. (2010). Understanding how consumer view green hotels : how hotels green image can influence behavioral intentions. Journal of Sustainable Tourism, Vol $18(7$ September 2010). doi:http://dx.doi.org/10.1080/096695 $\underline{81003777747}$

Manaktola, K., \& Jauhari, V. (2007). Exploring cosumer attitude, and behaviour towards green practices in the lodging industry in India. Journal of Contemporary Hospitality Management, 15(No 5). doi:https://doi.org/10.1108/0959611 0710757534

Mohsan, F., Nawaz, M. M., Khan, S., Shaukat, Z., \& Aslam, N. (2011). Impact of Customer Satisfaction on Customer Loyalty and Intentions to Switch: Evidence from Banking Sector of Pakistan International Journal of Business and Social Science, 2(16).
Orie Berezan, Carola Raab, Michelle Yoo, \& Love, C. (2013). Sustainable hotel practices and nationality: The impact on guest satisfaction and Guest Intention to Return International Journal of Hospitality Management, 34, 227- 233. doi:http://dx.doi.org/10.1016/j.ijhm. $\underline{\text { 2013.03.010 }}$

R.A.Ganiyu, I. Ikechuwku, \& A.O. Elizabeth. (2012). Is Customer Satisfaction an Indicator of Customer Loyalty? . Australian Journal of Business and Management Research, 2(7), 14-20.

Saleem, H., \& Raja, N. S. (2014). The Impact of Service Quality on Customer Satisfaction, Customer Loyalty and Brand Image: Evidence from Hotel Industry of Pakistan. Middle-East Journal of Scientific Research, 19 (5), 706-711. doi:https://doi.org/10.9790/487X$\underline{1616117122}$

Srivastava, M. (2015). Influencers of Customer Satisfaction Customer Loyalty Relationship: A Conceptual Research Model. Indore Management Journal, 7(1).

Sundaraju, S., Kee, D. M. H., Lopez, R. D., Balakrishnan, Y., \& Sagadevan, Y. (2019). Research on U Hotel. International Jounal of Tourism and Hospitality in Asia Pasific (IJTHAP), 2(1), 1-3. doi:https://doi.org/10.32535/ijthap.v $\underline{2 \mathrm{i} 2.525}$

Tabachnick, B. G., \& Fidell, L. S. (2013). Using Multivariate Statistics (6th ed.). Boston US: Pearson. 
Taherdoost, H. (2016). Validity and Reliability of the Research Instrument; How to Test the Validation of a Questionnaire/Survey in a Research. International Journal of Academic Research in Management (IJARM), 3(5), $\quad 28 \quad-\quad 36$. doi:https://doi.org/10.2139/ssrn.3205 $\underline{040}$

Wisker, Z. L., \& Kwiatek, P. (2018). The Effects of Environmental Orientation on Firm Performance and a Mediating Role of Employee-Based Brand Equity: A comparative study. International Journal of Applied Business \& International Management (IJABIM), 3(2). doi:https://doi.org/10.32535/ijabim.v $\underline{3 \mathrm{i} 2.157}$

Wolok, T. (2019). Analysis of The Effect of Green Marketing on Consumer Purchasing Decisions on The Body Shop Gorontalo Product. International Journal of Applied Business \& International Management (IJABIM), 4(2). doi:https://doi.org/10.32535/ijabim.v $\underline{4 i 2.569}$

Young, W., Hwang, K., Donald, S. M., \& Oates, C. J. (2010). Sustainable Consumption: Green Consumer Behaviour when Purchasing Products. Sustainable Development, $18, \quad 20 \quad-31$. doi:https://doi.org/10.1002/sd.394

Yu, Y., Li, X., \& Jai, T.-M. C. (2017). The Impact of Green Experience on Customer Satisfaction : Evidence from TripAdvisor. International Journal of Contemporary Hospitality Management, 29(5), 1340-1361. doi:https://doi.org/10.1108/IJCHM07-2015-0371 